\title{
Artikel
}

\section{Over de houdbaarheid van de parlementaire immuniteit voor (gemeentelijke) volksvertegenwoordigers}

\author{
Mr. dr. drs. B. van der Vorm*
}

\section{Inleiding}

De vrijheid van meningsuiting van politici is een groot goed, maar waar ligt de grens met het begaan van strafbare uitlatingen, zoals groepsbelediging en het aanzetten tot haat? Dit is een actuele vraag, die veel juridische pennen in beweging heeft gezet. ${ }^{1}$ De Hoge Raad heeft zich inmiddels verschillende malen gebogen over deze kwestie en hij heeft een toetsingskader uiteengezet (de zogenoemde contextuele toetsing) voor groepsbelediging, dat een standaard is geworden voor de interpretatie van dit delict. ${ }^{2}$ Er kan worden aangenomen dat politici een ruime vrijheid van meningsuiting toekomt, maar dat deze niet absoluut is. ${ }^{3}$ Dit is ook in lijn met artikel 10, tweede lid, EVRM. Deze jurisprudentie ziet op uitlatingen van politici in het publieke debat en niet op de besloten context van een vergadering van de StatenGeneraal. Parlementariërs die zich tijdens een officiële vergadering van de Staten-Generaal beledigend uitlaten tegenover andere parlementariërs kunnen hiervoor niet worden vervolgd of civielrechtelijk worden aangespro-

* Mr. dr. drs. B. van der Vorm is universitair docent straf(proces)recht en verbonden aan het Willem Pompe Instituut en het Montaigne Centrum voor Rechtspleging en Conflictoplossing van de Universiteit Utrecht en tevens redacteur van dit tijdschrift.

1. Zie bijvoorbeeld L.A. van Noorloos, 'Het einde van een tijdperk? Over godslastering, vrijheid van meningsuiting en het vernielen van heilige huisjes', Strafblad 2013, p. 450-459.

2. HR 9 januari 2001, NJ 2001/203

3. L.A. van Noorloos, 'De Hoge Raad over de vrijheid van meningsuiting van politici', Tijdschrift Praktijkwijzer Strafrecht 2015, p. 98-102. ken. Een parlementariër die tijdens een officiële vergadering de koning opzettelijk beledigt, hetgeen strafbaar is gesteld in artikel $111 \mathrm{Sr}$, kan hiervoor evenmin worden vervolgd. Hier geldt immers de parlementaire immuniteit. Dit betekent dat de immuniteit alle schriftelijke en mondelinge bijdragen dekt van immuniteitsgerechtigden aan de parlementaire vergadering. ${ }^{4} \mathrm{Op}$ deze wijze wordt een vrije politieke discussie mogelijk gemaakt en hoeven parlementariërs niet te vrezen voor een strafrechtelijke vervolging, zo is de ratio van deze vorm van immuniteit. De kern van de parlementaire immuniteit wordt gevormd door artikel 71 Grondwet. Niet uitsluitend binnen de vergaderingen van de StatenGeneraal geldt parlementaire immuniteit; deze geldt ook op het decentrale niveau, zoals de gemeente. Op grond van artikel 22 Gemeentewet geldt immuniteit voor immuniteitsgerechtigden voor hetgeen in de raadsvergadering is gezegd of aan deze schriftelijk is overgelegd. De werking van deze bepaling kan aan de hand van het volgende voorbeeld worden geillustreerd. Tijdens een raadsvergadering wordt door een raadslid het volgende tegen een ander raadslid gezegd: 'Wat ben je toch een gemeen leugenachtig rotwijf." Onder normale omstandigheden kan een dergelijke uiting worden angemerkt als belediging in de zin van artikel $266 \mathrm{Sr}$ en is degene die de belediging heeft geuit hiervoor vervolgbaar. Aangezien deze uiting echter is gedaan tijdens een officiële vergadering, is het Openbaar Ministerie niet-ontvankelijk om over te gaan tot vervolging. Het voorgaande

4. R.J.B. Schutgens, 'Parlementaire immuniteit', in: Immuniteiten (Handelingen Nederlandse Juristen-Vereniging 2013-I), Kluwer: Deventer 2013, p. 18.

5. Vgl. de zaak die leidde tot HR 16 mei 2017, NJ 2017/320, m.nt. R.J.B. Schutgens; Gst. 2017/123, m.nt. J.L.W. Broeksteeg. 
betekent evenwel niet dat gemeenteraadsleden onbegrensd beledigende uitspraken kunnen doen in de raadsvergadering. De voorzitter kan namelijk ordemaatregelen nemen tegen raadsleden die de orde tijdens de raadsvergadering verstoren, zoals vermanen, het woord ontnemen en uitsluiten van de vergadering. Het is evenwel de vraag waarom deze strafrechtelijke immuniteit in dergelijke gevallen zou moeten gelden. Zijn de kosten, namelijk de opoffering van de rechtsbescherming van beledigden, niet te hoog ten opzichte van de baten, te weten de bescherming van het algemeen belang? ${ }^{6}$

In deze bijdrage wordt onderzocht in hoeverre de parlementaire immuniteit - in het bijzonder de strafrechtelijke immuniteit - van volksvertegenwoordigers houdbaar is, waarbij eveneens ruimschoots aandacht wordt besteed aan artikel 22 Gemeentewet. Teneinde deze vraag te beantwoorden wordt ten eerste aandacht besteed aan de kernbepaling, waarin de strafrechtelijke immuniteit is neergelegd, namelijk artikel 71 Grondwet (paragraaf 2). Ten tweede worden de reikwijdte en de strekking van artikel 22 Gemeentewet besproken (paragraaf 3), waarna ten derde de argumenten vóór en tegen de parlementaire immuniteit in kaart worden gebracht (paragraaf 4). Ten vierde volgt een analyse over de houdbaarheid van de parlementaire immuniteit, toegespitst op artikel 22 Gemeentewet (paragraaf 5). Er wordt besloten met een conclusie (paragraaf 6).

\section{De reikwijdte en strekking van artikel 71 Grondwet}

De parlementaire immuniteit op het niveau van het Rijk is neergelegd in artikel 71 Grondwet. Uit deze grondwettelijke bepaling blijkt dat de leden van de StatenGeneraal, de ministers, de staatssecretarissen en andere personen die deelnemen aan de beraadslaging, niet in rechte kunnen worden vervolgd of aangesproken voor hetgeen zij in de vergaderingen van de Staten-Generaal of van commissies daaruit hebben gezegd of aan deze schriftelijk hebben overgelegd. Met deze bepaling wordt beoogd om de zelfstandigheid en de onafhankelijkheid van de volksvertegenwoordigers ten opzichte van de regering en andere staatsmachten te waarborgen. Ten gevolge van artikel 71 Grondwet worden parlementariërs gevrijwaard van strafrechtelijke vervolging voor hun mondelinge en schriftelijke bijdrage aan het parlementaire debat, maar ook zijn tuchtrechtelijke en civielrechtelijke aansprakelijkheid uitgesloten. De term 'parlementaire immuniteit' is hiermee een overkoepelend begrip: strafrechtelijke, tuchtrechtelijke en civielrechtelijke immuniteit zijn hier een onderdeel van. In zijn preadvies ontleedt Schutgens artikel 71 Grondwet en brengt in kaart wie als immuniteitsgerechtigde personen worden aangeduid, welke gedragingen door de immuniteit worden gedekt, op welke situaties de immuniteit van

6. Vgl. Schutgens 2013, p. 47. toepassing is en tegen welke sancties de immuniteit beschermt. $^{7}$

Indien een blik wordt geworpen op de grondwettelijke bepaling van artikel 71 Grondwet, blijkt dat de leden van de Staten-Generaal, de ministers, de staatssecretarissen en andere personen die deelnemen aan de beraadslaging, immuniteitsgerechtigd zijn. Ten aanzien van de categorie 'andere personen die deelnemen aan de beraadslaging' kunnen misverstanden ontstaan. Niet alle derden die in de Kamer het woord voeren, zijn namelijk aan te duiden als immuniteitsgerechtigden. De immuniteit wordt uitsluitend verleend aan derden die door een bewindspersoon of Kamerlid zijn aangewezen om hen bij de beraadslaging bij te staan, zo wordt door Schutgens opgemerkt. ${ }^{8}$ Derden die krachtens artikel 69 , derde lid, Grondwet als hulppersoon worden aangewezen - bijvoorbeeld ten aanzien van de verdediging van complexe wetsvoorstellen - verkrijgen immuniteit. ${ }^{9}$ Andere derden dan hulppersonen zijn aldus niet immuniteitsgerechtigd. ${ }^{10}$ Ook personen die door een Kamer of Kamercommissie in een vergadering of hoorzitting worden gehoord zonder hen toe te laten tot de beraadslaging, komt geen immuniteit toe.

De immuniteit strekt zich uit tot alle schriftelijke en mondelinge bijdragen van de immuniteitsgerechtigden aan de parlementaire vergadering. ${ }^{11}$ Een immuniteitsgerechtigde die tijdens de parlementaire vergadering aanzet tot haat, discriminatie of geweld, hetgeen strafbaar is gesteld in artikel $137 \mathrm{~d} \mathrm{Sr}$, kan hiervoor niet worden vervolgd. Hetzelfde geldt voor een immuniteitsgerechtigde die tijdens de officiële vergadering dreigt een terroristisch misdrijf te plegen: deze persoon kan niet worden vervolgd wegens overtreding van artikel $285 \mathrm{Sr}$. De gesproken woorden kunnen niet worden onttrokken aan de immuniteit 'met het argument dat zij onvoldoende verband hielden met het parlementaire debat of dat er buiten de orde werd gesproken.' ${ }^{12}$ Schutgens heeft aangegeven dat de immuniteit is gericht op alle uitingen tijdens de officiële vergadering. ${ }^{13}$ Deze immuniteit is begrensd tot schriftelijke en mondelinge bijdragen, zodat andere gedragingen hier niet onder vallen. Een parlementariër die bijvoorbeeld tijdens een parlementaire vergadering een geweldsdelict pleegt of zich schuldig maakt aan vernieling, kan hiervoor worden vervolgd.

Uit het voorgaande is gebleken dat de parlementaire immuniteit is gericht op het gesproken en het geschreven woord, waarbij een functionele relatie tussen de uiting en het onderwerp van debat niet hoeft te bestaan. ${ }^{14}$ De bescherming van het gesproken woord is formeel begrensd: de uitingen dienen te zijn gedaan tijdens een vergadering van de Staten-Generaal of van commissies daaruit, zo blijkt uit artikel 71 Grondwet. Het reglement

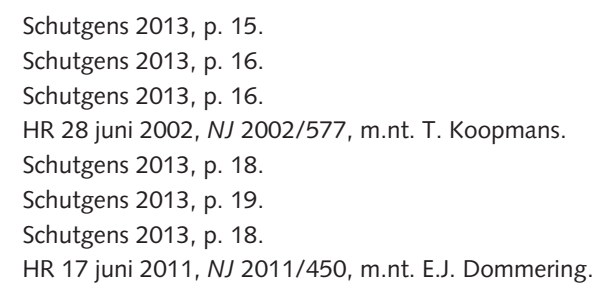


van orde is in dezen bepalend. Als sprake is van een reglementaire Kamer- of commissievergadering, treedt de immuniteit in werking. Hieruit volgt dat een informeel overleg tussen Kamerleden en vergaderingen van Kamerfracties niet vallen onder de immuniteit. ${ }^{15}$ Daarnaast is de immuniteit van toepassing op situaties waarbij de immuniteitsgerechtigde stukken aan de StatenGeneraal overlegt. Schutgens geeft aan dat hiertoe in ieder geval de stukken behoren die de immuniteitsgerechtigde ter verdere verspreiding binnen de Kamer of een Kamercommissie aan de griffie toezendt. Rechtstreekse toezending van stukken aan derden en rechtstreeks aan het bestuur gerichte correspondentie worden volgens Schutgens niet gedekt door de immuniteit. ${ }^{16}$ Deze formele grenzen worden door de rechtspraak strikt bewaakt. ${ }^{17}$ De immuniteit geldt dus niet voor gedragingen van Kamerleden buiten het parlement. ${ }^{18}$

Artikel 71 Grondwet biedt niet uitsluitend bescherming tegen strafrechtelijke (en tuchtrechtelijke) vervolging, maar eveneens beschermt deze immuniteit tegen civiele aansprakelijkheid. Alle vormen van overheidsrechtspraak worden door de parlementaire immuniteit geblokkeerd. ${ }^{19}$ Volgens Schutgens zou de parlementaire immuniteit ook dienen te beschermen tegen buitengerechtelijke sanctionering, zoals berisping door een leidinggevende. ${ }^{20}$

$\mathrm{Nu}$ het Openbaar Ministerie geen vervolgingsrecht heeft inzake uitingen van immuniteitsgerechtigden tijdens een parlementaire vergadering en ook civiele aansprakelijkheid is uitgesloten, is het de vraag of de parlementaire immuniteit ook kan worden misbruikt. Deze vraag laat zich eenvoudig beantwoorden: dat is zeer wel mogelijk. ${ }^{21}$ Een belangrijke rol is weggelegd voor de Kamervoorzitter. Op grond van de Reglementen van Orde van de Kamers heeft de voorzitter de bevoegdheid om tegen de Kamerleden ordemaatregelen te treffen. Zo kan de voorzitter bijvoorbeeld beledigende stukken zonder nadere mededeling terzijde leggen en kan de voorzitter ten aanzien van mondelinge opmerkingen de Kamerleden vermanen, het woord ontnemen en uitsluiten van de vergadering. ${ }^{22}$ Dit betekent overigens niet dat de voorzitter in alle gevallen ook daadwerkelijk optreedt tegen onparlementair of onfatsoenlijk taalgebruik. Zo greep de voorzitter van de Tweede Kamer niet in toen een Kamerlid van de PVV het Nederlandse parlement omschreef als een 'nepparlement'. ${ }^{23}$ Tijdens

15. Schutgens 2013, p. 19.

16. Schutgens 2013, p. 20.

17. Schutgens 2013, p. 20.

18. P.P.T. Bovend'Eert, 'Commentaar op art. $71 \mathrm{GW}^{\prime}$, in: P.P.T. Bovend'Eert, J.L.W. Broeksteeg, D.E. Bunschoten, J.W.A. Fleuren \& H.G. Hoogers (red.), Tekst \& Commentaar Grondwet, Deventer: Wolters Kluwer 2015 (ook online)

19. Schutgens 2013, p. 22.

20. Schutgens 2013, p. 22. De vraag kan worden opgeworpen of dit ook in overeenstemming is met de oorspronkelijke ratio van de immuniteit: de bescherming van de volksvertegenwoordiger tegen een rechterlijke interventie.

21. E.C.M. Jurgens, 'Een gedurfde stelling', TvCR 2010, p. 325.

22. P.P.T. Bovend'Eert \& H.R.B.M. Kummeling, Het Nederlandse parlement (elfde druk), Deventer: Kluwer 2010, p. 147 e.v.

23. Handelingen // 2015/16, nr. 11. een debat in de Eerste Kamer leidde het bezigen van dezelfde uiting wel tot optreden van de voorzitter. ${ }^{24}$

\section{De reikwijdte en strekking van artikel 22 Gemeentewet}

\subsection{De inhoud van artikel 22 Gemeentewet}

De immuniteit ten aanzien van gemeenteraadsleden berust niet op artikel 71 Grondwet, maar deze vorm van immuniteit wordt ontleend aan artikel 22 Gemeentewet. ${ }^{25}$ De ratio van deze bepaling is hetzelfde als zijn grondwettelijke equivalent: een raadslid dient zijn opvattingen vrij te kunnen verkondingen zonder het risico te lopen om voor de inhoud daarvan in rechte ter verantwoording te worden geroepen. ${ }^{26} \mathrm{Uit}$ deze bepaling blijkt dat de leden van het gemeentebestuur en andere personen die deelnemen aan de beraadslaging niet in rechte kunnen worden vervolgd of aangesproken voor, dan wel worden verplicht getuigenis af te leggen als bedoeld in artikel 165, eerste lid, van het Wetboek van Burgerlijke Rechtsvordering over hetgeen zij in de vergadering van de raad hebben gezegd of aan de raad schriftelijk hebben overgelegd. Een verschil tussen artikel 71 Grondwet en artikel 22 Gemeentewet is erin gelegen dat de laatstgenoemde bepaling de immuniteit aanvult met een verschoningsrecht. ${ }^{27}$

Artikel 22 Gemeentewet is van toepassing op leden van het gemeentebestuur en andere personen die deelnemen aan de beraadslaging. Onder het gemeentebestuur verstaat artikel 5 Gemeentewet ieder bevoegd orgaan van de gemeente. Dit zijn de raad, het college van burgemeester en wethouders en de burgemeester. Ook commissies en ambtenaren kunnen worden aangemerkt als gemeentebestuur voor zover ze een orgaan van de gemeente zijn. De immuniteit die volgt uit artikel 22 Gemeentewet geldt dus niet uitsluitend voor raadsleden, maar voor elk lid van het gemeentebestuur. Hiermee wordt bedoeld 'ieder die individueel of gezamenlijk met andere leden van een college gemeentelijke bevoegdheden uitoefent.' ${ }^{28}$ Daarnaast kunnen ook andere personen die deelnemen aan de beraadslaging aanspraak maken op immuniteit. In dit verband kan worden gedacht aan personen die de raad bijstaan, zoals gemeenteambtenaren die voor de raad zijn gevraagd ten

24. 'Eerste Kamervoorzitter tolereert PVV-uitspraak "nepparlement" niet', de Volkskrant 13 oktober 2015.

25. Vgl. artikel 22 Provinciewet, artikel 39 Waterschapswet, artikel 21 Wet op de bedrijfsorganisatie (SER) en artikel 89 Wet op de bedrijfsorganisatie (bedrijfslichamen)

26. Kamerstukken I/ 1989/90, 19 403, nr. 16, p. 48

27. Aan leden van het gemeentebestuur en andere personen die aan de beraadslaging deelnemen is het verschoningsrecht toegekend, hetgeen inhoudt dat zij in rechte kunnen weigeren getuigenis af te leggen. Dit verschoningsrecht is geenszins een vanzelfsprekendheid. Vgl. F.A.C. Meijer van Meijbeek, 'Hoge Raad: Geen verschoningsrecht voor gemeenteraadsleden', NG 1987, p. 40.

28. P.A.M.J. Graat, 'Commentaar op art. 22 Gemw', in: T.D. Cammelbeeck \& R. Nehmelman (red.), Tekst \& Commentaar Gemeentewet Provinciewet, Deventer: Wolters Kluwer 2017 (ook online). 
aanzien van bepaalde zaken de raad schriftelijk of mondeling van advies te dienen. ${ }^{29}$ Als sprake is van deelname aan de beraadslaging dan moet worden beantwoord aan het reglement van orde. ${ }^{30}$ Het bepaalde in artikel 22 Gemeentewet is niet van toepassing op insprekers, voordat de officiële vergadering van de raad begint, omdat zij niet deelnemen aan de beraadslaging. De immuniteit is derhalve een plaatselijk voorrecht, aangezien deze uitsluitend geldt ten aanzien van hetgeen zich tijdens de raadsvergadering of de vergadering van de bestuurscommissie afspeelt.

\subsection{De jurisprudentiële uitleg van artikel 22 Gemeentewet}

Uit jurisprudentie over artikel 22 Gemeentewet blijkt dat de immuniteit zich niet uitstrekt tot andere handelingen dan welke in deze bepaling worden genoemd. Zo heeft de Hoge Raad overwogen dat een raadslid geen strafrechtelijke immuniteit toekomt ten aanzien van een tekst van zijn redevoering in de raad aan een ander dan de (leden) van de raad, namelijk een journalist, buiten de raadsvergadering. ${ }^{31}$ In deze zaak is de verdachte - met goedkeuring van de Hoge Raad - veroordeeld wegens het in het openbaar bij geschrift aanzetten tot haat tegen mensen wegens hun ras en/of godsdienst, hetgeen strafbaar is gesteld in artikel $137 \mathrm{~d} \mathrm{Sr}$. Annotator Mevis geeft bij dit arrest aan dat de strikte uitleg van de Hoge Raad - namelijk het beperken tot de feitelijke handelingen die in artikel 22 Gemeentewet worden genoemd - past in de achtergrond van artikel 22 Gemeentewet: 'het publieke belang dat de deelnemers aan de vergadering van deze organen, de gekozen leden daarvan voorop, zich in de vergadering van het orgaan vrijelijk kunnen uiten opdat in en door die vergadering de democratische controle op het openbaar bestuur goed kan worden uitgeoefend. ${ }^{32}$ In de onderhavige zaak is het cruciaal dat het raadslid zijn tekst aan de journalist heeft overhandigd, zodat het niet kan worden aangemerkt als een handeling ter uitoefening van de taak van de gemeenteraad of commissie daaruit, daartoe in vergadering bijeen. Deze handeling van het raadslid wordt derhalve niet door de immuniteit beschermd.

Soms proberen raadsleden die gebruikmaken van onparlementair taalgebruik zich te verschuilen achter de immuniteit die wordt geboden in artikel 22 Gemeentewet. Zo kan worden gewezen op een raadslid dat tijdens een schorsing van de raadsvergadering in de burgemeesterskamer een ander raadslid toespreekt met de woorden 'Du verkenskop'. Een beroep van de verdachte op de strafrechtelijke immuniteit baat niet, omdat de gewraakte uitingen niet zijn gedaan tijdens een officiële vergadering. ${ }^{33}$

29. Kamerstukken I/ 1985/86, 19 403, nr. 3, p. 81

30. Kamerstukken // 1985/86, 19 403, nr. 3, p. 81.

31. HR 2 april 2002, NJ 2002/421, m.nt. P.A.M. Mevis.

32. Zie de derde opmerking in de annotatie van P.A.M. Mevis onder HR 2 april 2002, NJ 2002/421. Zie eveneens HR 24 juni 1983, NJ 1984/801, m.nt. M. Scheltema.

33. Gerechtshof 's-Hertogenbosch 25 januari 2017, NJFS 2017/98.
Dit voorbeeld staat niet op zich. In een andere zaak heeft een lid van de raad, dat eveneens lid is van de werkgeverscommissie, aan een ander lid van de raad, ook lid van deze commissie, in een overleg over het functioneren van een griffier enige beledigende termen geuit. Dit lid is vervolgd wegens belediging. ${ }^{34}$ Door het gerechtshof is bewezen verklaard dat:

'zij op 16 juli 2014 te Alphen aan den Rijn opzettelijk beledigend [betrokkene 1] in dier tegenwoordigheid mondeling heeft toegevoegd de woorden "vuile leugenaar" en "klerewijf" en/of "tyfuswijf", althans woorden van gelijke beledigende aard en strekking.'

Volgens de verdachte is het Openbaar Ministerie nietontvankelijk in de vervolging, omdat zij strafrechtelijke immuniteit zou genieten ten aanzien van de gewraakte uitlatingen. Deze zouden volgens de verdachte zijn gedaan tijdens een vergadering van de Werkgeverscommissie. Het staat echter vast dat de uitlatingen zijn gedaan tijdens een informeel overleg zonder voorzitter en zonder notulist. De Hoge Raad gaat akkoord met de constatering dat geen sprake is van een vergadering van de bestuurscommissie en de verdachte geen immuniteit toekomt. Annotator Broeksteeg geeft bij dit arrest aan dat dit een juist uitgangspunt is; een informeel overleg is immers geen vergadering van de bestuurscommissie. Broeksteeg vraagt zich in dit verband wel af wanneer sprake is van een officiële vergadering en wanneer van een informeel overleg:

'Dat zal niet altijd helder zijn, maar hangt af van de vraag of een convocatie is verzonden, of de vergadering wordt voorgezeten door haar (vaste) voorzitter, of notulen worden opgemaakt, of zij wordt geleid volgens de voorschriften van een reglement van orde, etc. Het enkel ontbreken van één van deze elementen hoeft nog niet te betekenen dat geen sprake is van een 'officiële' commissievergadering - maar het kán wel betekenen dat zij informeel van aard is. Indien enkele elementen ontbreken, zal sneller sprake zijn van een informele vergadering. De rechter zal dat toetsen naar de omstandigheden van het geval. Indien alle betrokkenen, zoals hier het geval is, menen dat de vergadering informeel is, zal de rechter dat annemen. Er bestaat dan immers geen verschil van opvatting over de aard van de vergadering. ${ }^{35}$

In de onderhavige zaak kon de verdachte zich niet op de strafrechtelijke immuniteit beroepen vanwege de strikte interpretatie van de Hoge Raad ten aanzien van artikel 22 Gemeentewet. Indien de verdachte deze gewraakte uitlatingen echter had gedaan in de vergadering van de bestuurscommissie dan zou het Openbaar Ministerie geen vervolgingsrecht toekomen. De controle op het geuite dient dan vanuit het orgaan zelf of van de voorzit-

34. HR 16 mei 2017, NJ 2017/320, m.nt. R.J.B. Schutgens; Gst. 2017/123, m.nt. J.L.W. Broeksteeg.

35. Zie de vierde opmerking in de annotatie van J.L.W. Broeksteeg onder HR 16 mei 2017, Gst. 2017/123. 
ter te komen. Annotator Schutgens betreurt de ingestelde vervolging in deze zaak:

'Zelfs in casu, waar terecht geen immuniteit werd aangenomen, valt het mijns inziens te betreuren dat een onverkwikkelijke scheldpartij niet door bemiddeling van gezaghebbende lokale politici opgelost is kunnen worden, maar dat in plaats daarvan de politie en de strafrechter zijn ingeschakeld - hoe begrijpelijk het ook moge zijn dat de voorzitter van de Alphense Werkgeverscommissie zich niet door een collega wilde laten uitmaken voor leugenachtig teringwijf. ${ }^{36}$

Het standpunt van Schutgens kan ik niet delen. In zaken waarin de toepasselijkheid van de parlementaire immuniteit ter discussie staat, is een belangrijke rol weggelegd voor de Hoge Raad. Kennelijk was in deze zaak sprake van twijfel over de vraag in hoeverre de parlementaire immuniteit van toepassing is in dit geschil. Voor de rechtsontwikkeling is het van belang dat deze vorm van immuniteit niet wordt onttrokken aan een rechterlijke toetsing.

\section{De argumenten vóór en tegen de parlementaire immuniteit van artikel 71 Grondwet}

\subsection{Inleiding}

De vraag naar de houdbaarheid van de parlementaire immuniteit is meerdere malen gesteld en op verschillende wijzen beantwoord. Ongeveer honderd jaar geleden werd er reeds gediscussieerd over de houdbaarheid van deze vorm van immuniteit. ${ }^{37}$ Enige tijd geleden heeft zich in de literatuur een discussie voorgedaan, die was gericht op een eventuele uitbreiding van de parlementaire immuniteit. Tijdens deze discussie stond vooral de werking van artikel 71 Grondwet centraal. In deze paragraaf worden de voor- en nadelen van de parlementaire immuniteit, zoals bedoeld in artikel 71 Grondwet, nader in kaart gebracht.

\subsection{De argumenten vóór de (uitbreiding van de) parlementaire immuniteit}

Schutgens heeft terecht aangegeven dat wortels van de parlementaire immuniteit liggen in 'vervlogen tijden'. 38 In zijn preadvies worden door Schutgens verschillende argumenten genoemd, die pleiten vóór de (handhaving

36. Zie de achtste opmerking in de annotatie van R.J.B. Schutgens onder HR 16 mei 2017, NJ 2017/320.

37. W.A.E. van Os, De gerechtelijke onvervolgbaarheid der volksvertegenwoordigers, Groningen: J.B. Wolters 1910, p. 137 e.v. Vgl. P. de Morree, 'Parlementaire immuniteit: discutabel privilege of onmisbaar instrument?', in: R. Nehmelman (red.), Parlementaire immuniteit vanuit een Europese context bezien, Nijmegen: Wolf Legal Publishers 2010, p. 25-48.

38. Zie de achtste opmerking in de annotatie van R.J.B. Schutgens onder HR 16 mei 2017, NJ 2017/320. van de) parlementaire immuniteit. Ten eerste wijst hij erop dat de parlementariër - en dit geldt mutatis mutandis ook voor het gemeenteraadslid - onbevreesd en zonder het risico van een rechterlijke interventie moet kunnen zeggen, waarvan hij meent dat het in het openbaar belang is. ${ }^{39}$ Een tweede argument dat door Schutgens wordt geidentificeerd is gelegen in de scheiding der machten. Deze argumenten worden eveneens door de (civiele kamer van de) Hoge Raad onderschreven:

'Parlementaire immuniteit zoals hier aan de orde vormt een beperking van het recht op toegang tot de rechter. Zij dient echter een legitiem doel, te weten het beschermen van de vrije meningsuiting in het parlement en handhaving van de scheiding van machten tussen de wetgever en de rechter (vgl. HR 28 juni 2002, LJN AE1544, NJ 2002/577 en EHRM 17 december 2002, application nr. 35373/97 (A. tegen het Verenigd Koninkrijk)). Met dat doel is niet verenigbaar dat, zoals aanvaarding van de door het middel voorgestane opvatting zou meebrengen, de rechter zich zou begeven in een beoordeling van de - in dit geval: civielrechtelijke - toelaatbaarheid van in het parlement gedane uitingen, welke dan ook. ${ }^{40}$

De parlementaire immuniteit beschermt de onafhankelijke positie van het parlement en zijn voorzitter tegen de mogelijke interventie van een rechter (bescherming tegen de rechters), maar deze vorm van immuniteit belet eveneens dat rechters worden geconfronteerd met politieke vragen (bescherming van de rechter). Ook beschermt de parlementaire immuniteit de volksvertegenwoordiging tegen het Openbaar Ministerie, die het vervolgingsrecht zou kunnen misbruiken om parlementariërs - maar ook gemeenteraadsleden - voor kritische uitingen in het parlement te vervolgen. ${ }^{41}$ Schutgens komt tot de conclusie dat de parlementaire immuniteit zou moeten blijven bestaan:

'Deze doelen zijn van harte te onderschrijven. Weliswaar worden zij in ons huidige rechtssysteem grotendeels verzekerd door de ruime "algemene" uitingsvrijheid en de onafhankelijkheid en professionaliteit van onze rechterlijke macht, maar dat neemt niet weg dat de parlementaire immuniteit, zoals wel meer beproefde constitutionele waarborgen, zuinig bewaard zou moeten worden voor tijden dat het staatsbestel in zwaarder weer geraakt. Bovendien is de scheiding der machten ook in een moderne samenleving gebaat bij de parlementaire immuniteit, die het parlement alléén verantwoordelijk maakt voor het bewaken van de orde in eigen huis en de rechter buiten parlementaire ruzies houdt. ${ }^{42}$

Ook Elzinga is een voorstander van de parlementaire immuniteit. Ten eerste stelt hij dat ten onrechte in de

\footnotetext{
9. Schutgens 2013, p. 33.

HR 17 juni 2011, NJ 2011/450, r.o. 3.4.2

Schutgens 2013, p. 34-37.

Schutgens 2013, p. 37.
} 
discussie over de houdbaarheid van deze vorm van immuniteit wordt gesproken van een voorrecht voor volksvertegenwoordigers; zij kunnen immers niet volledig straffeloos hun gang gaan. Er bestaan namelijk ordemaatregelen. Ten tweede dient de immuniteit behouden te blijven om de parlementariërs te beschermen tegen een inmenging van de rechter. Tot slot wijst Elzinga erop dat de parlementaire immuniteit een belangrijke uitstralingskracht heeft. ${ }^{43}$ In navolging van Elzinga is De Morree van mening dat de parlementaire immuniteit nog steeds een belangrijke functie heeft in het Nederlandse staatsrecht. ${ }^{44}$ Deze mening is ook Munneke toegedaan:

'Tegenover de nadelen van de onvervolgbaarheid staan belangrijke staatsrechtelijke waarborgen: de vrije meningsuiting in het debat, en de scheiding van machten tussen rechter en volksvertegenwoordiging. Een rechter die moet gaan beoordelen welke uitlatingen in een parlement nog door de beugel kunnen, begeeft zich op glad ijs. Het is dan ook te begrijpen dat de Hoge Raad geen ruimte voor rechterlijke bemoeienis ziet. ${ }^{45}$

De parlementaire immuniteit gaat sommigen echter niet ver genoeg. Peters geeft aan dat deze vorm van immuniteit uitsluitend valt uit te leggen vanuit een historisch perspectief, maar de hedendaagse realiteit miskent. Hij betoogt dat de bescherming van het gesproken woord van Kamerleden moet worden uitgebreid tot buiten het parlement, omdat daar voornamelijk het politieke debat plaatsvindt. ${ }^{46}$ De beperking van de meningsuiting kan naar zijn mening worden gevonden in het oproepen van geweld, het puur schelden en het om nieuwsgierigheidsredenen schenden van iemands privacy. ${ }^{47}$ Ook Nehmelman is een voorstander van de uitbreiding van de immuniteit. ${ }^{48}$ Naar zijn mening moeten parlementariërs zich ook buiten het parlementaire debat ten volle kunnen laten horen, waarbij vervolging evenwel mogelijk moet zijn. Hiervoor dient dan eerst de immuniteit van het betreffende Kamerlid door de volksvertegenwoordiging te worden opgeheven. ${ }^{49}$

43. D.J. Elzinga, 'Parlementaire onschendbaarheid voor volksvertegenwoordigers, verouderd instituut of onmisbare bescherming?', in: D.J. Elzinga (red.), De staat van het recht. Opstellen over staatsrecht en politiek, Zwolle: W.E.J. Tjeenk Willink 1990, p. 132-133.

44. De Morree 2010, p. 31

45. S.A.J. Munneke, 'Orde en onvervolgbaarheid', Gst. 2012, p. 1.

46. J.A. Peters, 'Immuniteit ook buiten het parlementair debat', TVCR 2010, p. 329.

47. Peters 2010, p. 330

48. Nadien lijkt Nehmelman echter te worstelen met de vraag of de parlementaire immuniteit moet worden uitgebreid. Zie P.W. den Hollander, 'Worstelen met immuniteiten. De jaarvergadering van de NJV', NJB 2013, p. 1859

49. R. Nehmelman, 'De verboden politieke meningsuiting als ambtsmisdrijf', in: R. Nehmelman (red.), Parlementaire immuniteit vanuit een Europese context bezien, Nijmegen: Wolf Legal Publishers 2010, p. 23. Zie ook R. Nehmelman, 'Spreken is zilver, maar wie bepaalt of zwijgen goud is?', AA 2011, p. 355.
4.3. De argumenten tegen de (uitbreiding van de) parlementaire immuniteit

Al sinds het begin van de twintigste eeuw gingen er stemmen op om de parlementaire immuniteit in het geheel af te schaffen. Van Os identificeerde meerdere argumenten tegen de parlementaire immuniteit. Ten eerste wees hij erop dat de historische reden voor de parlementaire immuniteit goeddeels was weggevallen. Ten tweede werden politieke minderheden voldoende rechten toegekend om voor hun belangen op te komen en konden ze niet door de politieke meerderheid bij wet tot zwijgen worden gebracht. Ten derde was de rechterlijke macht voldoende onafhankelijk en onpartijdig om zich over een politieke kwestie uit te spreken. Ten vierde wees Van Os erop dat volkssoevereiniteit losstaat van immuniteit. Ten vijfde hoeft uit de essentie van het wezen van de volksvertegenwoordiging geenszins de onvervolgbaarheid voort te vloeien. Tot slot was het volgens Van Os onjuist om aan te nemen dat de parlementaire immuniteit moest worden gehandhaafd, omdat zij een algemeen doel dient. Hij wees op andere organen die eveneens een algemeen doel dienden, terwijl het ontbreken van immuniteit niet tot problemen leidde. ${ }^{50}$

In lijn met deze contra-argumenten zijn ook belangrijke nadelen jegens de uitbreiding van de parlementaire immuniteit te ontwaren. Een uitbreiding van de immuniteit zou immers betekenen dat parlementariërs - en ook gemeenteraadsleden - buiten het parlement consequent worden voorgetrokken ten opzichte van bijvoorbeeld journalisten en ambteloze burgers die zich in de publieke discussie mengen. ${ }^{51}$ Een uitbreiding van de immuniteit zou eveneens strijd kunnen opleveren met het bepaalde in artikel 71 Grondwet. ${ }^{52}$ Voorts zou een uitbreiding mogelijk problematisch zijn in het licht van jurisprudentie van het EHRM over artikel 6 EVRM. ${ }^{53}$ Ten derde zou de uitbreiding van de immuniteit volgens Schutgens tot een 'waar mediacircus' kunnen leiden. ${ }^{54}$ Tot slot wijst Schutgens op de ruime uitleg die wordt gegeven aan de vrijheid van meningsuiting. Naar zijn mening biedt deze ruime uitleg van de algemene vrijheidsuitleg voldoende bescherming aan de parlementariërs en hoeft de immuniteit daarom niet te worden uitgebreid. Deze vrijheid van meningsuiting is niet onbegrensd. Van Noorloos merkt het volgende op over de uitlatingen van politici in het publieke debat.

'Enerzijds moet een politicus in staat zijn zaken van algemeen belang aan de orde te stellen, ook als zijn uitlatingen daarbij kunnen kwetsen, choqueren of verontrusten. Anderzijds draagt een politicus in het publieke debat een verantwoordelijkheid om te voorkomen dat hij uitlatingen verspreidt die strijdig zijn

50. W.A.E. van Os, De gerechtelijke onvervolgbaarheid der volksvertegenwoordigers, Groningen: J.B. Wolters 1910, p. 82-136.

51. Schutgens 2013, p. 39.

52. Jurgens 2010, p. 326.

53. Schutgens 2013, p. 40-41

54. Schutgens 2013, p. 41. 
met de wet en met de grondbeginselen van de democratische rechtsstaat. ${ }^{55}$

Politici die buiten het parlement uitlatingen verspreiden die strijdig zijn met het Wetboek van Strafrecht kunnen hiervoor worden vervolgd, omdat de immuniteit in deze situatie niet geldt. ${ }^{56}$ Schutgens ziet de parlementaire immuniteit vooral als een waarborg in de situatie dat 'het rechtsstatelijke klimaat buiten guur wordt.' ${ }^{57} \mathrm{De}$ contra-argumenten van Schutgens zijn mijns inziens overtuigend: een uitbreiding van de immuniteit tot buiten het parlement is niet zinvol. ${ }^{58}$

\section{De houdbaarheid van de parlementaire immuniteit van artikel 22 Gemeentewet}

\subsection{De parlementaire immuniteit en de schending van de geheimhoudingsplicht}

De discussie over het al dan niet afschaffen van de parlementaire immuniteit ziet vooral op het bepaalde in artikel 71 Grondwet. Zoals is gebleken wordt door sommigen ervoor gepleit om deze vorm van immuniteit uit te breiden, omdat het politieke debat steeds vaker ook buiten het parlement wordt gevoerd. Ten aanzien van Kamerleden is dit wellicht het geval, maar geldt dit ook voor gemeenteraadsleden? Een uitbreiding van de parlementaire immuniteit in de zin dat deze zich ook uitstrekt buiten de officiële vergaderingen van de StatenGeneraal, waardoor mogelijk strijd ontstaat met artikel 71 Grondwet, ${ }^{59}$ zou ontegenzeggelijk consequenties hebben voor het bepaalde in artikel 22 Gemeentewet. Een uitbreiding betekent per definitie dat gemeenteraadsleden eveneens immuniteit genieten voor uitingen buiten de raadsvergadering. Dat dit tot ongewenste situaties kan leiden, laat zich illustreren aan de spanning tussen de immuniteit en de schending van de geheimhoudingsplicht. Naar aanleiding van een incident in de gemeenteraad van de Gemeente Ede is een discussie ontstaan over de vraag in hoeverre een gemeenteraadslid met succes een beroep kan doen op het bepaalde in artikel 22 Gemeentewet, indien hij de geheimhoudingsplicht van artikel 25 Gemeentewet schendt. Kan het betreffende gemeenteraadslid worden vervolgd wegens overtreding van artikel $272 \mathrm{Sr}$, als hij tijdens een officiële vergadering van de raad uit de school klapt?

De meeste auteurs zijn het erover eens dat een schending van de geheimhoudingsplicht als onwenselijk

55. Van Noorloos 2015, p. 100

56. Vgl. A.J. Nieuwenhuis, 'Tussen grondrechtelijke vrijheid en parlementaire onschendbaarheid: de vrijheid van meningsuiting van de parlementariër', TVCR 2010, p. 23.

57. Schutgens 2013, p. 42.

58. Anders: J. van Sintmaartendijk, 'Een parlementariër en zijn vrijheid van meningsuiting. De parlementaire onschendbaarheid naar het huidige tijdsbeeld vertaald', NJB 2011, p. 2087-2093.

59. Jurgens 2010, p. 326. wordt ervaren, maar dat de strafrechtelijke immuniteit het gemeenteraadslid beschermt tegen een strafrechtelijke vervolging. ${ }^{60}$ Volgens Hennekens is het echter mogelijk dat het raadslid wordt vervolgd ter zake van overtreding van artikel $272 \mathrm{Sr}$.

'Mijn standpunt ten aanzien van het onderhavige vraagstuk is al lang(er) bekend en houdt daarentegen in dat de immuniteit zoals in de Gemeentewet is geregeld en de bepaling waarbij straf op schending van de geheimhoudingsplicht in het Wetboek van Strafrecht is vastgelegd naast elkaar staan. Deze twee bepalingen regelen naar mijn oordeel elk een 'eigen' specifiek aspect. Zij hebben ieder voor zich op een ander onderwerp betrekking en in zoverre geen relatie met elkaar: de ene ziet op het mogen openbaren van door straf gesanctioneerde meningsuitingen en de andere op het verbod om een geheim in de openbaarheid te brengen.' ${ }^{\prime 1}$

Hennekens lijkt te veronderstellen dat artikel 22 Gemeentewet slechts een blokkade vormt om een - in casu - gemeenteraadslid te vervolgen wegens uitingsdelicten. Ten aanzien van andere delicten dan uitingsdelicten zou de immuniteit van artikel 22 Gemeentewet zich niet strekken. In navolging van Schutgens kan worden betoogd dat artikel 22 Gemeentewet een algemene blokkade opwerpt tegen vervolging van het raadslid jegens zijn uitingen in de officiële vergadering. Artikel 22 Gemeentewet is derhalve te beschouwen als een lex specialis ten opzichte van artikel 272 Sr. Een gemeenteraadslid dat zijn geheimhoudingsplicht tijdens een officiële raadsvergadering schendt, kan onder de huidige werking van artikel 22 Gemeentewet door het Openbaar Ministerie niet worden vervolgd ter zake van overtreding van artikel 272 Sr. Schutgens merkt hier het volgende over op:

'Beide bepalingen kunnen niet tegelijkertijd worden toegepast, en omdat artikel 22 Gemw een specifieke groep personen in een bijzonder geval beschermt, krijgt het voorrang boven het algemenere artikel 272 Sr.' ${ }^{62}$

Het is in dergelijke gevallen de taak van de voorzitter om sanctionerend op te treden. Voor een rechterlijke interventie is hier geen plaats. Om deze problematiek het hoofd te bieden zijn voorstellen gedaan om de immuniteit te beperken. Zo wordt door Hoos voorgesteld om de volksvertegenwoordiging het recht te geven om de immuniteit op te heffen, zodat ambtsdragers in

60. C.J.N. Versteden, 'Maatregelen tegen schending van de geheimhoudingsplicht door immuniteit genietende raadsleden', Gst. 2010, p. 237-241; N. Hoos, 'Een maas in de wet. Het lekken van geheime informatie door immuniteitsrechtigde ambtsdragers', NJB 2012, p. 662-666; R.J.B. Schutgens, 'Ook uit de school klappende raadsleden zijn immuun', NJB 2015, p. 629.

61. H.Ph.J.A.M. Hennekens, 'Derogeert immuniteit aan de geheimhoudingsplicht? De relatie tussen de artikelen 22 Gemeentewet en 272 Wetboek van Strafrecht', NJB 2015, p. 102-105

62. Schutgens 2015, p. 629 
bijzondere gevallen van opzettelijke schending van een geheimhoudingsplicht kunnen worden vervolgd. Zij erkent evenwel dat er nadelen zijn verbonden aan dit voorstel. ${ }^{63}$

\subsection{Een weging van de argumenten vóór en tegen de parlementaire immuniteit}

Indien nogmaals een blik wordt geworpen op de argumenten vóór de immuniteit, kan niet worden ontkend dat het garanderen van een veilige haven voor het gesproken en geschreven woord tijdens de officiële vergadering een groot goed is. En in navolging van Schutgens kan worden opgemerkt dat de immuniteit een waarborg is in rechtsstatelijk minder zonnige tijden. ${ }^{64}$ Het argument van de scheiding der machten wordt in deze discussie ook naar voren gebracht. Er zou geen rol zijn weggelegd voor de rechterlijke macht inzake het politieke debat. De volksvertegenwoordigers dienen tijdens een officiële vergadering te worden beschermd tegen de rechter, maar de rechter dient eveneens te worden beschermd tegen het politieke proces. ${ }^{65}$ Dit zijn belangrijke redenen om de immuniteit te handhaven. Aan de andere kant dient voor ogen te worden gehouden dat de immuniteit stamt uit een periode waarin deze daadwerkelijk noodzakelijk was, maar naar de huidige tijdsgeest achterhaald lijkt te zijn. Peters omschrijft dit als volgt:

'De parlementaire immuniteit werd ingevoerd in een wereld die er wel even anders uitzag dan de huidige. Sommige staatsrechtelijke beginselen en concepten blijven gehandhaafd terwijl ze hun ware betekenis al lang verloren hebben. Ze overleven zichzelf en raken vermolmd. Dat is nu ook het geval met het immuniteitsbeginsel. ${ }^{66}$

Het feit dat de parlementaire immuniteit moet worden aangeduid als een 'ouderwets rechtsfiguur', zoals Schutgens het terecht verwoordt ${ }^{67}$ betekent niet dat het dáárom geen betekenis meer zou hebben. Het argument van de scheiding der machten, in het bijzonder tussen de rechterlijke macht en de volksvertegenwoordiging, lijkt mij evenwel niet geheel overtuigend. Zo kunnen volksvertegenwoordigers voor uitlatingen buiten de officiële vergadering wel worden vervolgd. Het argument van de scheiding der machten geldt dus niet ten aanzien van uitlatingen van volksvertegenwoordigers buiten de vergadering. Daarnaast kan eveneens worden gewezen op de situatie in Duitsland: in dit land wordt geen immuniteit verleend aan volksvertegenwoordigers voor beledigingen tijdens het debat in een officiële vergadering. ${ }^{68}$ Het argument van de scheiding der machten gaat hier dus niet op. Naar mijn mening komt aan het argument van de scheiding der machten hoofdzakelijk een histori-

63. Hoos 2012, p. 664-666

64. Schutgens 2013, p. 42.

65. Schutgens 2013, p. 34-37

66. Peters 2010, p. 328.

67. Zie de achtste opmerking in de annotatie van R.J.B. Schutgens onder HR 16 mei 2017, NJ 2017/320.

68. Van Sintmaartensdijk 2011, p. 2089. sche betekenis toe en is bovendien een ontwikkeling gaande waarbij de scheiding der machten steeds meer wordt tenietgedaan. ${ }^{69}$

Een belangrijk voordeel van de parlementaire immuniteit is volgens Schutgens, zoals eerder opgemerkt, gelegen in de mogelijkheid om de politiek buiten de rechtszaal te houden. Hij ziet in dit verband geen rol voor de rechterlijke macht, maar voor de politiek zelf:

'Mij lijkt het (straf)recht slechts een ultimum remedium om (de verplatting van?) het politieke proces in het gareel te houden. Het justitieel apparaat moet hier bij voorkeur niet mee lastig gevallen worden (het geeft te denken dat hier in hoger beroep ook het OM zich op de parlementaire immuniteit van verdachte beriep om zijn eigen niet-ontvankelijkheid te bepleiten). De eerst aangewezene daarvoor is de politiek zélf. ${ }^{70}$

Met Schutgens kan worden ingestemd dat het strafrecht dient te worden beschouwd als een ultimum remedium en dat het primaat van de handhaving bij de politiek zelf dient te liggen, namelijk bij de voorzitter. Naar mijn mening wordt het echter problematisch indien de voorzitter niet handhavend optreedt. Onder dergelijke omstandigheden kan een vervolging mij opportuun lijken, bijvoorbeeld indien een volksvertegenwoordiger een burger opzettelijk in een kwaad daglicht stelt.

Hieraan kan worden gekoppeld dat de vrijheid van meningsuiting wordt beschouwd als een groot goed en ook ruim wordt uitgelegd door de rechter. Een absolute uitingsvrijheid geldt uiteraard niet, maar het Openbaar Ministerie dient terughoudend te zijn met het instellen van een vervolging jegens politici inzake mogelijke strafrechtelijke uitlatingen buiten de officiële vergadering. In navolging van Schutgens kan evenwel worden opgemerkt dat de ruime uitleg voldoende waarborg dient aan de volksvertegenwoordigers. De vrijheid van meningsuiting die is neergelegd in artikel $10 \mathrm{EVRM}$ dekt zowel de discussie buiten als binnen het parlement. ${ }^{71}$ Indien de immuniteit zou worden opgeheven kan worden tegengeworpen dat volksvertegenwoordigers niet meer vrijuit zouden kunnen spreken tijdens een officiële vergadering. Dit is echter een onjuiste voorstelling van zaken. Ook in het huidige regime kunnen volksvertegenwoordigers niet straffeloos hun gang gaan; de voorzitter kan - en wellicht zelfs moet - ordemaatregelen nemen tegen volksvertegenwoordigers die bijvoorbeeld beledigingen uiten, oproepen tot haat en hun geheimhoudingsplicht schenden. Wat is dan de daadwerkelijke toegevoegde waarde van de immuniteit? Het voorkomen van een rechterlijke interventie? Naar mijn mening leidt een afschaffing van de immuniteit niet tot de situatie dat

69. In dit verband kan worden gewezen op de OM-afdoening. Ten aanzien van minder ernstige strafbare feiten kan de officier van justitie zelfstandig een straf opleggen. Bezien vanuit de scheiding der machten betekent dit dat de uitvoerende macht op de stoel van de rechterlijke macht is gaan zitten.

70. Zie de achtste opmerking in de annotatie van R.J.B. Schutgens onder HR 16 mei 2017, NJ 2017/320.

71. Nieuwenhuis 2010, p. 22. 
volksvertegenwoordigers niet meer vrijelijk kunnen spreken tijdens de officiële vergadering. De ruime uitleg van de vrijheid van meningsuiting biedt immers voldoende bescherming. Ook is de vrees niet gerechtvaardigd dat het Openbaar Ministerie achteloos tot vervolging over zal gaan en mocht het Openbaar Ministerie toch vervolgen dan is altijd de mogelijkheid aanwezig dat de volksvertegenwoordiger een geslaagd beroep kan doen op een (bijzondere) strafuitsluitingsgrond, zoals overmacht in de zin van noodtoestand ter zake van de schending van de geheimhoudingsplicht. Mijns inziens is vooral een rol voor het Openbaar Ministerie weggelegd, indien een volksvertegenwoordiger, zoals een gemeenteraadslid, de grenzen van de vrijheid van meningsuiting overtreedt, door bijvoorbeeld het aanzetten tot haat, en hier tijdens de officiële vergadering door de voorzitter niet tegen wordt opgetreden. Met andere woorden: het primaat blijft liggen bij de voorzitter. In dit verband dient evenwel voor ogen te worden gehouden dat sprake is van een 'toenemende parlementaire spelverruwing', waarbij de voorzitter onvoldoende gebruik lijkt te maken van de 'scheidsrechtersbevoegdheid'. ${ }^{72}$ Buruma en Drion zijn eveneens niet overtuigd van de reglementaire bevoegdheden van de voorzitter, wanneer sprake is van uit de hand gelopen debatten. ${ }^{73}$ Munneke erkent terecht dat op dit punt veel wordt gevraagd van de voorzitter en de raad. ${ }^{74}$

Al met al zijn dus belangrijke redenen aanwezig om de immuniteit die is neergelegd in artikel 22 Gemeentewet - en eveneens in artikel 71 Grondwet - op te heffen. Van belang is dat volksvertegenwoordigers de ruimte hebben om zich te uiten in het maatschappelijke en politieke belang. Thans wordt de vrijheid van meningsuiting voldoende gewaarborgd door de ruime uitleg van artikel 10 EVRM, waardoor tegenwoordig voor parlementaire immuniteit geen noodzaak meer lijkt te zijn.

\section{Conclusie}

Van oudsher kunnen volksvertegenwoordigers, op zowel centraal en decentraal niveau, niet aansprakelijk worden gesteld voor hetgeen zij tijdens een officiële vergadering hebben gezegd of schriftelijk hebben overhandigd. Zij genieten immuniteit. Deze immuniteit is gegrond op artikel 71 Grondwet en op het niveau van de gemeente nader uitgewerkt in artikel 22 Gemeentewet. Reeds lange tijd is de parlementaire immuniteit omstreden. Er zijn redenen aanwezig om deze vorm van immuniteit te handhaven. De immuniteit biedt volksvertegenwoordigers een veilige haven voor het gesproken en geschreven woord tijdens de officiële vergadering en in rechtsstatelijk minder zonnige tijden biedt het een waarborg tegen willekeurige vervolging. Naar de huidige maatstaven

72. Zie de vierde opmerking in de annotatie van E.J. Dommering onder HR 17 juni 2011, NJ 2011/450.

73. Y. Buruma \& C. Drion, ‘De jaarvergadering van de NJV over Immuniteiten', NJB 2013, p. 1501

74. Munneke 2012, p. 1. kunnen echter twijfels ontstaan naar de toevoegde waarde van deze vorm van immuniteit. Zo wordt het publieke debat steeds meer gevoerd buiten de officiële vergadering om en wordt de vrijheid van meningsuiting - zoals bedoeld in artikel $10 \mathrm{EVRM}$ - van politici ruim uitgelegd. De vrijheid van meningsuiting is niet onbegrensd; van politici wordt naast het bieden van een ruime uitingsvrijheid evenwel verantwoordelijkheid in het publieke debat verwacht. Deze ruime uitleg van de vrijheid van meningsuiting biedt voldoende waarborgen voor politici in het publieke debat, waardoor de immuniteit aan toegevoegde waarde verliest. Hoewel het - in lijn met de algemene uitkomst van de jaarvergadering van de NJV uit 2013 aangaande immuniteiten ${ }^{75}$ - niet mijn verwachting is dat de parlementaire immuniteit in de nabije toekomst zal worden afschaft, verworven immuniteiten worden immers vooral gekoesterd, ${ }^{76}$ dienen dergelijke immuniteiten voortdurend met een kritische blik te worden beschouwd.
75. Den Hollander 2013, p. 1857.

76. Zo ook de controversiële strafrechtelijke immuniteit van de overheid, zie o.m. J.A.F. Peters, 'Wordt niet vervolgd..... Over vervolging van overheden en het wetsontwerp-Wolfsen als gemiste kans', NTB 2016, p. 1-4. Van de Hoge Raad hoeft geen ommezwaai te worden verwacht. Zie de vierde opmerking in de annotatie van J.M. Reijntjes onder HR 24 september 2013, NJ 2014/241. 